\title{
Improvement of Nutritional Quality of Some Oilseed Meals Through Solid- State Fermentation Using Aspergillus niger
}

\author{
Aydın Altop ${ }^{1, a, *}$, Emrah Güngör ${ }^{1, b}$, Güray Erener ${ }^{1, c}$ \\ ${ }^{I}$ Department of Animal Science, Faculty of Agriculture, Ondokuz Mayis University, 55270 Samsun, Turkey \\ *Corresponding author

\begin{tabular}{l|l}
\hline A R T I C L E I N F O & A B S T R A C T \\
\hline Research Article & $\begin{array}{l}\text { This study aimed to investigate the effect of solid-state fermentation on the nutritional composition } \\
\text { of cottonseed meal (CSM), sunflower meal (SFM) and hazelnut kernel meal (HKM). In this study, } \\
\text { each feedstuff was divided into two treatment groups (unfermented and fermented) with five } \\
\text { replicates. Nutritional changes in the feedstuffs were determined by analyzing crude protein, ether } \\
\text { extract, ash, crude fiber, neutral detergent fiber, acid detergent fiber contents. Solid-state } \\
\text { fermentation had effects on the nutritional composition in all feedstuffs. The best improvement in } \\
\text { nutritional quality was obtained from the HKM with increasing the crude protein and decreasing the } \\
\text { structural carbohydrates content. Fermented HKM can be considered as an alternative protein feed } \\
\text { for soybean meal considering the nutritional composition. }\end{array}$ \\
$\begin{array}{l}\text { Received : 30/05/2019 } \\
\text { Accepted : 08/08/2019 }\end{array}$
\end{tabular}

Aspergillus niger

Protein feed

Cottonseed meal

Sunflower meal

Hazelnut kernel meal \section{(1)}


problems, especially for non-ruminant animals (Tasan et al., 2011). Therefore, it was suggested that SFM could be used only up to $10-15 \%$ in poultry diets (Calıslar and Kustimur, 2017).

The hazelnut was produced approximately, 550 thousand tons per year in Turkey, which constituted $42 \%$ of the world's total hazelnut production (TUIK, 2018). The HKM is a by-product produced after obtaining the oil from the nuts. The protein content of HKM varies between 39$43 \%$ depending on the extraction process of oil (Erener and Altop, 2008). Although HKM has the potential plant protein sources in animal nutrition, it contains higher cellulose or tannin and insufficient in terms of amino acids such as lysine, methionine, and threonine. These factors limits to usage of HKM in animal nutrition (Erener et al., 2003).

In recent years, solid-state fermentation has been considered as a useful and inexpensive method to improve the nutritional composition of feedstuffs and to eliminate its antinutritional factors. Previous studies reported that improvement of both protein quantity and quality (Mathivanan et al., 2006; Zhang et al., 2012), degradation of non-starch polysaccharides to monosaccharides such as glucose and eliminating of possible antinutritional factors (Zhao et al., 2013) in feedstuffs and agricultural residues by solid-state fermentation. Given all this information, it may be possible to improve the nutritional composition of CSM, SFM, and HKM. Therefore, the effects of solid-state fermentation on the nutritional composition of CSM, SFM, and HKM were examined in this study.

\section{Materials and Methods}

\section{Microorganism and Feedstuffs}

CSM, SFM, and HKM were obtained from commercial sources and ground to a size of $2 \mathrm{~mm}$. Aspergillus niger (ATCC 9142) obtained from American Type Culture Collection (ATCC) was used as the inoculant. A. niger was incubated at $24^{\circ} \mathrm{C}$ for 7 days according to agar plate technique. Spores counted in a hemacytometer cell with Fuchs-Rosenthal ruling. Prepared cultures were inoculated $\left(10^{5}\right.$ per $\left.100 \mathrm{~g}\right)$ into the substrates on the same day.

\section{Solid-state Fermentation}

After the autoclaving process $\left(121^{\circ} \mathrm{C}, 10 \mathrm{~min}\right)$, each CSM, SFM and HKM sample was divided into two treatment group (unfermented and fermented) with five replicates. Fermentation media was prepared by $100 \mathrm{~g}$ solid substrate (CSM, SFM or HKM) and $160 \mathrm{~g}$ PDA broth (Merck). A. niger inoculated to the substrates at $10^{6}$ spores for each $100 \mathrm{~g}$ solid media. After gentle mixing, the substrates were incubated at $28-30^{\circ} \mathrm{C}$ for 7 days. At the end of this period, fermented feeds were dried in polythene sheets under the room temperature and milled to pass through a $2 \mathrm{~mm}$ sieve.

\section{Main Nutritional Composition}

The CSM, SFM, and HKM samples were analyzed for dry matter (DM), crude protein $(\mathrm{CP})$, ether extract (EE), ash according to AOAC (2000) and for crude fiber (CF), neutral detergent fiber (NDF), acid detergent fiber (ADF) and acid detergent lignin (ADL) by fiber analyzer (A2000, Ankom) according to Van Soest et al. (1991) before and after fermentation. Hemicellulose was calculated as NDF minus ADF. Nitrogen-free extract (NFE) was estimated on a dry weight basis by subtracting the percentages of $\mathrm{CP}$, EE, CF and ash from $100 \%$.

\section{Statistical Analysis}

Data from unfermented and fermented feedstuffs were separately analyzed with the Student t test (SPSS 21.0 Statistics). Normality of distribution was tested with Shapiro-Wilk's test. Differences were considered significant at $\mathrm{P}<0.05$.

\section{Results}

Solid state fermentation affected the nutritional composition of CSM, SFM, and HKM (Table 1, Table 2 and Table 3, respectively). The crude protein content of HKM and SFM were increased $(\mathrm{P}<0.001)$ although The CP of CSM was not affected (P>0.05). After fermentation, the EE content of CSM and SFM were decreased $(\mathrm{P}<0.05$ and $\mathrm{P}<0.001$, respectively) but not the EE content of HKM $(\mathrm{P}>0.05)$. Ash content in all groups was increased $(\mathrm{P}<0.01)$. Although a decrease in the NFE content of SFM and HKM was observed $(\mathrm{P}<0.001)$, the NFE content of CSM was increased $(\mathrm{P}<0.01)$ after fermentation.

After fermentation, although crude fiber of CSM content did not affect $(\mathrm{P}>0.05)$, its NDF, ADF and ADL contents $(\mathrm{P}<0.01, \mathrm{P}<0.001$ and $\mathrm{P}<0.05$, respectively) were increased. There was an increase $(\mathrm{P}<0.001, \mathrm{P}<0.01$ and $\mathrm{P}<0.05$, respectively) in crude fiber, $\mathrm{ADF}$ and $\mathrm{ADL}$ content of SFM, but not to affect $(\mathrm{P}>0.05)$ its NDF content. Crude fiber, NDF and ADF content of HKM were decreased ( $\mathrm{P}<0.001, \quad \mathrm{P}<0.001$ and $\mathrm{P}<0.01$, respectively) by fermentation while there was no significant $(\mathrm{P}>0.05)$ effect of the fermentation on the ADL content of HKM. Hemicellulose content of all oilseed meals was decreased $(\mathrm{P}<0.05)$ by fermentation.

Table 1 Chemical composition of unfermented and fermented CSM (\% DM)

\begin{tabular}{|c|c|c|c|c|}
\hline Composition (\% DM) & CSM & FCSM & SEM & $\mathrm{P}$ \\
\hline Crude Protein & 20.39 & 19.66 & 0.359 & NS \\
\hline Ether Extract & 8.56 & 5.18 & 0.773 & $* * *$ \\
\hline Ash & 8.39 & 9.70 & 0.312 & $* *$ \\
\hline NFE & 31.99 & 34.89 & 0.679 & $* *$ \\
\hline Crude Fiber & 30.67 & 30.57 & 0.210 & NS \\
\hline NDF & 51.65 & 53.29 & 0.380 & $* *$ \\
\hline $\mathrm{ADF}$ & 39.70 & 43.13 & 0.782 & $* * *$ \\
\hline $\mathrm{ADL}$ & 10.79 & 13.84 & 0.778 & $*$ \\
\hline Hemicellulose & 11.95 & 10.16 & 0.405 & $* * *$ \\
\hline
\end{tabular}


Table 2 Chemical composition of unfermented and fermented SFM

\begin{tabular}{|c|c|c|c|c|}
\hline Composition (\% DM) & SFM & FSFM & SEM & $\mathrm{P}$ \\
\hline Crude Protein & 33.00 & 41.53 & 1.912 & $* * *$ \\
\hline Ether Extract & 1.47 & 0.86 & 0.150 & $*$ \\
\hline Ash & 7.38 & 9.87 & 0.558 & $* * *$ \\
\hline NFE & 37.72 & 24.69 & 2.923 & $* * *$ \\
\hline Crude Fiber & 20.43 & 23.05 & 0.594 & $* * *$ \\
\hline $\mathrm{NDF}$ & 34.67 & 36.07 & 0.484 & NS \\
\hline $\mathrm{ADF}$ & 23.82 & 26.15 & 0.580 & $*$ \\
\hline ADL & 8.53 & 10.71 & 0.525 & $* *$ \\
\hline Hemicellulose & 10.85 & 9.92 & 0.238 & $*$ \\
\hline
\end{tabular}

Table 3 Chemical composition of unfermented and fermented HKM (\% DM)

\begin{tabular}{|c|c|c|c|c|}
\hline Composition (\% DM) & HKM & FHKM & SEM & $\mathrm{P}$ \\
\hline Crude Protein & 44.66 & 58.40 & 3.088 & $* * *$ \\
\hline Ether Extract & 1.00 & 1.62 & 0.235 & NS \\
\hline Ash & 8.60 & 10.88 & 0.516 & $* * *$ \\
\hline NFE & 31.97 & 20.51 & 2.577 & $* * *$ \\
\hline Crude Fiber & 13.78 & 8.60 & 1.159 & $* * *$ \\
\hline NDF & 32.43 & 25.27 & 1.617 & $* * *$ \\
\hline $\mathrm{ADF}$ & 22.44 & 19.36 & 0.719 & $* *$ \\
\hline $\mathrm{ADL}$ & 12.46 & 14.52 & 0.603 & NS \\
\hline Hemicellulose & 9.99 & 5.91 & 0.915 & $* * *$ \\
\hline
\end{tabular}

** $=\mathrm{P}<0.01, * * *=\mathrm{P}<0.001, \mathrm{NS}=$ not significant, $\mathrm{HKM}=$ hazelnut kernel meal, FHKM = fermented hazelnut kernel meal, NFE = nitrogen-free extract, $\mathrm{SEM}=$ standart error of means.

\section{Discussion}

The study showed that the nutritional quality of CSM, SFM and HKM through solid-state fermentation using Aspergillus niger were improved. These results were similar to studies which was reported that Fermented CSM (Zhang et al., 2007), SFM (Jannathulla et al., 2018), palm kernel cake (Iluyemi et al., 2006; Lawal et al., 2010), sour cherry kernel (Güngör et al., 2017) and grape seed (Altop et al., 2018) were higher nutrient value as compared to their unfermented.

In general, $\mathrm{CP}$ contents of the oil seed meal were increased after fermentation in the study. This increase may be due to A. niger spore counts on the substrates because it is a microbial protein source and has highly nutrient value. In the study, increased A. niger spores during to fermentation could be increased CP content of the meals (Altop et al., 2018). Therefore, it need to detailed studies on protein quality and quantity of the meals.

The NFE indicates the carbohydrates, sugars, starches and other easily degradable non-nitrogenous substances in the feed. Microorganisms prefer to utilize the soluble carbohydrates rather than other nutrients to meet its carbon requirements (Papagianni, 2007). Jannathulla et al. (2018) reported a decrease in the NFE content of SFM and soybean meal by fermentation. In this study, fermentation decreased the amount of NFE in SFM, as well as in HKM. Similar findings were also reported in the studies on shea nut meal (Dei et al., 2008), sour cherry kernel (Güngör et al., 2017) and grape seed (Altop et al., 2018). However, fermentation increased the NFE content of CSM in this study in contrast to the results of the studies mentioned above. This may indicate that $A$. niger did not choose the NFE for a carbon source or could not grow properly in CSM or both. Indeed, fermentation did not change the nutritional composition of CSM efficiently compared with the SFM and HKM in this study. Similarly, Apata (2011) reported increasing NFE content of the Indian almond meal after fermentation.

Jannathulla et al. (2018) showed that A. niger decreased the ether extract content of SFM and soybean meal. Similarly, ether extract was decreased by fermentation in CSM and SFM in the present study. A. niger can produce lipase enzymes in solid-state fermentation (Kumar and Kanwar, 2012), which can be the reason of the diminishing of ether extract content. Similar results were noted in the studies on the Indian almond meal (Apata, 2011) and mango kernel (Kayode and Sani, 2008).

Cellulolytic enzymes such as cellulase (Xie et al., 2016) and hemicellulase (Mathivanan et al., 2006) can be produced by $A$. niger in solid-state fermentation. In the present study, hemicellulose content was decreased by fermentation in all feeds. Similarly, crude fiber, NDF, and ADF content decreased in HKM after fermentation. Jannathulla et al. (2018) noted that crude fiber, NDF and ADF content of SFM and soybean meal were decreased through fermentation. Similar findings were reported in previous studies on palm kernel cake (Iluyemi et al., 2006; Lawal et al., 2010), Indian almond meal (Apata, 2011), grape seed (Altop et al., 2018). However, solid-state fermentation increased the crude fiber, ADF, ADL content of SFM and NDF, ADF and ADL content of CSM in this study. Similar results were reported in the studies on sour cherry kernel (Güngör et al., 2017), mango kernel (Kayode and Sani, 2008). Cellulosic components increased by fermentation because of the fact that the cell wall of $A$. niger contains chitin, a cellulose-like component (Beauvais et al., 2014). Moreover, raising of structural carbohydrates contents may be due to the reduction of the other nutrients. 
Fermentation increased ash contents in all groups. This increase may be due to the decreased nutrients by fermentation instead of the actual increase. Similar results were obtained from the studies on shea nut meal (Dei et al., 2008), sour cherry kernel (Güngör et al., 2017), mango kernel (Kayode and Sani, 2008), grape seed (Altop et al., 2018).

\section{Conclusion}

In conclusion, A. niger solid-state fermentation improved the nutritional quality of SFM and HKM although desired effects were not observed in CSM. Nutritional quality of HKM had the highest improvement by fermentation with raising crude protein and reducing structural carbohydrates by fermentation. Fermented HKM can be recommended as a protein source for animal nutrition instead of soybean meal.

\section{References}

Altop A, Güngör E, Erener G. 2018. Aspergillus niger may improve nutritional quality of grape seed and its usability in animal nutrition through solid-state fermentation. International Advanced Researches and Engineering Journal, 2(3): 273-7.

AOAC. 2000. Official Methods of Analysis of AOAC International: 17th ed. Place of publication: USA: AOAC International.

Apata DF. 2011. Effect of Terminalia catappa fruit meal fermented by Aspergillus niger as replacement of maize on growth performance, nutrient digestibility, and serum biochemical profile of broiler chickens. Biotechnology Research International, 2011.

Beauvais A, Fontaine T, Aimanianda V, Latgé J-P. 2014. Aspergillus cell wall and biofilm. Mycopathologia, 178(5-6): 371-7.

Calislar S, Kustimur H. 2017. The effects of safflower meal on the performance, egg quality traits, yolk fatty acids and cholesterol levels in laying hens. Anadolu Journal of Agricultural Sciences, 32(2):269-78.

Dei H, Rose S, Mackenzie A, Amarowicz R. 2008. Growth performance of broiler chickens fed diets containing shea nut (Vitellaria paradoxa, Gaertn.) meal fermented with Aspergillus niger. Poultry Science, 87(9): 1773-8.

Erener G, Altop A. 2008. Growth and laying performances of Japanese quails fed hazelnut kernel meal diets enriched with L-lysine, DL-methionine and L-threonine. Revue de Medecine Veterinaire, 159(6): 338.

Erener G, Ozer A, Ocak N. 2003. Growth and laying performance of Japanese quail fed graded levels of hazelnut kernel oil meal incorporated into diets. Asian-australasian Journal of Animal Sciences, 16(12): 1789-94.

Ergin N, Kizil Aydemir S. 2018. Soya bitkisinin hayvan beslenmesindeki yeri ve önemi. International Journal of Eastern Mediterranean Agricultural Research, 1(1): 143-57.

Farran M, Barbour G, Usayran N, Kayouli C. 2010. Metabolizable energy and amino acid digestibility of decorticated extruded safflower meal. Poultry Science, 89(9):1962-6.

Güngör E, Altop A, Öztürk E, Erener G. 2017. Nutritional changes of sour cherry (Prunus cerasus) kernel subjected to Aspergillus niger solid-state fermentation. Journal of Tekirdag Agricultural Faculty:99-103.

Henry M, Pesti G, Bakalli R, et al. 2001. The performance of broiler chicks fed diets containing extruded cottonseed meal supplemented with lysine. Poultry Science, 80(6):762-8.

Iluyemi F, Hanafi M, Radziah O, Kamarudin M. 2006. Fungal solid state culture of palm kernel cake. Bioresource Technology, 97(3):477-82.

Jannathulla R, Dayal JS, Ambasankar K, Muralidhar M. 2018. Effect of Aspergillus niger fermented soybean meal and sunflower oil cake on growth, carcass composition and haemolymph indices in Penaeus vannamei Boone, 1931. Aquaculture, 486:1-8.
Jazi V, Boldaji F, Dastar B, Hashemi S, Ashayerizadeh A. 2017. Effects of fermented cottonseed meal on the growth performance, gastrointestinal microflora population and small intestinal morphology in broiler chickens. British Poultry Science, 58(4):402-8.

Kanyinji F, Sichangwa M. 2014. Performance of broilers fed finishing diets with fermented cotton seed meal as partial replacement for soybean meal. Journal of Animal Science Advances, 4:931-8.

Kayode R, Sani A. 2008. Physicochemical and proximate composition of mango (Mangifera indica) kernel cake fermented with mono-culture of fungal isolates obtained from naturally decomposed mango kernel. Life Science Journal, 5(4):55-63.

Kumar A, Kanwar SS. 2012. Lipase production in solid-state fermentation (SSF): recent developments and biotechnological applications. Dynamic Biochemistry, Process Biotechnology and Molecular Biology, 6(1):13-27.

Lawal T, Iyayi E, Adeniyi B, Adaramoye O. 2010. Biodegradation of palm kernel cake with multienzyme complexes from fungi and its feeding value for broilers. International Journal of Poultry Science, 9(7):695-701.

Mathivanan R, Selvaraj P, Nanjappan K. 2006. Feeding of fermented soybean meal on broiler performance. International Journal of Poultry Science, 5(9):868-72.

Özen N, Kırkpınar F, Özdoğan M, Ertürk MM, Yurtman IYY. 2005. Hayvan besleme. TMMOB Ziraat Mühendisleri Odas1 Türkiye Ziraat Mühendisliği VI Teknik Kongresi. Ankara.

Papagianni M. 2007. Advances in citric acid fermentation by Aspergillus niger: biochemical aspects, membrane transport and modeling. Biotechnology Advances, 25(3):244-63.

Tasan M, Gecgel U, Demirci M. 2011. Effects of storage and industrial oilseed extraction methods on the quality and stability characteristics of crude sunflower oil (Helianthus annuus L.). Grasas y Aceites, 62(4):389-98.

TUIK. 2018. Turkish Statistical Institute. http://www.turkstat.gov.tr /UstMenu.do?metod=temelist. Accessed date: 23.05.2019.

Van Soest Pv, Robertson J, Lewis B. 1991. Methods for dietary fiber, neutral detergent fiber, and nonstarch polysaccharides in relation to animal nutrition. Journal of Dairy Science, 74(10):3583-97.

Wang X, Tang J-w, Yao X-h, Wu Y-f, Sun H, Xu Y-x. 2012. Effect of Bacillus cereus $\mathrm{Br}$ on bacterial community and gossypol content during fermentation in cottonseed meal. African Journal of Microbiology Research, 6(36):6537-44.

Xie P, Huang L, Zhang C, Zhang Y-1. 2016. Nutrient assessment of olive leaf residues processed by solid-state fermentation as an innovative feedstuff additive. Journal of Applied Microbiology, 121(1):28-40. DOI: 10.1111/jam.13131.

Yenice E, Gültekin M, Kahraman Z, Ertekin B. 2018. The effects of the usage of solvent extracted safflower meal with soybean oil in the laying hen diets on the performance, egg quality and egg yolk fatty acid composition. Kafkas Üniversitesi Veteriner Fakültesi Dergisi, 24(3).

Zhang W-J, Xu Z-R, Zhao S-H, Sun J-Y, Yang X. 2007. Development of a microbial fermentation process for detoxification of gossypol in cottonseed meal. Animal Feed Science and Technology, 135(1-2):176-86.

Zhang X, Cao F, Sun Z, et al. 2012. Effect of feeding Aspergillus niger-fermented Ginkgo biloba-leaves on growth, small intestinal structure and function of broiler chicks. Livestock Science, 147(1-3): 170-80.

Zhao L, Zhang X, Cao F, Sun D, Wang T, Wang G. 2013. Effect of dietary supplementation with fermented Ginkgo-leaves on performance, egg quality, lipid metabolism and egg-yolk fatty acids composition in laying hens. Livestock Science, 155(1):77-85 